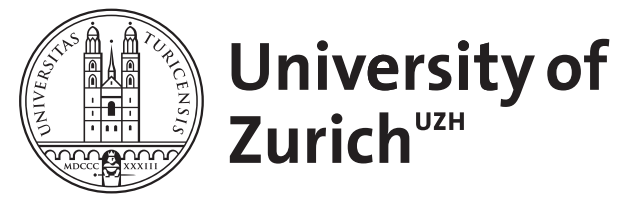

Zurich Open Repository and Archive

University of Zurich

University Library

Strickhofstrasse 39

CH-8057 Zurich

www.zora.uzh.ch

Year: 1992

The UNIDROIT draft convention on the international protection of cultural property

Siehr, Kurt

DOI: https://doi.org/10.1017/s0940739192000341

Posted at the Zurich Open Repository and Archive, University of Zurich ZORA URL: https://doi.org/10.5167/uzh-154003

Journal Article

Published Version

Originally published at:

Siehr, Kurt (1992). The UNIDROIT draft convention on the international protection of cultural property. International Journal of Cultural Property, 1(2):321-330.

DOI: https://doi.org/10.1017/s0940739192000341 


\title{
The UNIDROIT Draft Convention on the International Protection of Cultural Property
}

\author{
Kurt Siehr*
}

\section{History of the Draft Convention}

The preliminary draft Convention on stolen or illegally exported cultural objects, as approved by the UNIDROIT study group at its third session on 26 January 1990 and reprinted in our first issue, ${ }^{1}$ is the result of research being done in Rome since 1987. The Governing Council of the International Institute for the Unification of Private Law (UNIDROIT) decided at its 65th session in April 1986 to include in the research programme of the Institute the subject of the international protection of cultural property. ${ }^{2}$ This decision, however, was not taken by chance or because of no other reason than to contribute to an urgent problem of international legal and cultural relations. The Institute in Rome had already done some general research in the law on the acquisition in good faith of corporeal movables. ${ }^{3}$ This work attracted the interest of the UNESCO asking whether these general proposals could be made fruitful for the specific purposes of the protection of cultural property. Hence the UNESCO asked the Institute to prepare a Convention on stolen or illegally exported cultural objects. ${ }^{4}$

The research, mainly done by Professor Gerte Reichelt of the University of Vienna, could make use not only of the previous research programme of the Institute on acquisition in good faith of corporeal movables 5 but also of the UNESCO Convention of 14 November 1970 on the Means of Prohibiting and Preventing the Illicit Import, Export and Transfer of Ownership of Cultural Property $^{6}$ and of other materials. ${ }^{7}$ Additional materials and experiences were contributed by the members of the international study group in charge of the work programme on cultural property.

In May 1991 the draft of the Institute has already been discussed in the first session of government representatives and delegates of international organisations. The draft itself has not been modified by

\footnotetext{
* Professor of Law at the University of Zürich, Switzerland, Faculty of Law.
} 
this assembly composed of more than 100 persons. The participants rather raised some general questions and collected proposals with respect to most of the articles of the preliminary draft. ${ }^{8}$ The Institute hopes that after two additional sessions of official delegates a final version of a Convention will be ready for signature by government representatives.

\section{Basic Principles of the Draft Convention}

The Preliminary Draft has Five Chapters with Eleven Articles.

\subsection{General Principles}

a) As indicated by its name the draft distinguishes between stolen objects (mainly dealt with in Chapter II, Articles 3 and 4) and illegally exported objects (regulated in Chapter III by Articles 5-8). According to Art. 1 only in cases of an illegal export there has to be an international transaction. The provisions on stolen property also apply to purely domestic relations. ${ }^{9}$

b) Art. 2 gives an extremely wide and general definition of the notion 'cultural object' without distinguishing between objects of outstanding significance, objects of great importance for the cultural history of a certain state or tribe or objects of minor significance or secondary importance or objects of a certain age. ${ }^{10}$ Only in Art. 5(3), Arts. 6 and 7(a) are such categories of different kinds of cultural objects important.

c) If a cultural object has to be returned, the debtor in good faith is entitled to compensation, but only to a 'fair and reasonable' one: Art. 4(1) and Art. 8(1). This version has been chosen to enable the judge to take into account the financial resources of developing countries without being prohibited to order full compensation in other cases. ${ }^{11}$

\subsection{Restitution of Stolen Property}

a) There will be no bona fide acquisition of stolen property: Art. 3(1). Even an acquisitive prescription by possession in good faith (Ersitzung, usucapion, usucapione) is prohibited before the expiration of thirty years: Art. 3(2).

b) A claim for restitution has to be brought within a rather long period of three years from the time when the claimant knew or ought to have known the location of the object or its possessor: Art $3(2)$. In any case the claim has to be brought within thirty years since the object has been stolen: Art. 3(2).

c) A good faith purchaser of stolen cultural objects is entitled to 'fair and reasonable' compensation (supra 2.1(c)) if he proves that he 'exercised the necessary diligence when acquiring the the object': Art. 4(1) and (2). 


\subsection{Return of Illegally Exported Property}

a) The draft introduces in Art. 5 a claim of foreign Contracting States based on their own export legislation, thus deviating from a widely accepted conflicts rule and from public international law that a State is not obliged to enforce foreign provisions of public law regulating trade and commerce. ${ }^{12} \mathrm{Up}$ to now a State only succeeded to recover illegally exported cultural property when either the importing State prohibits import of cultural property without a valid foreign export licence ${ }^{13}$ or when the foreign State is owner of the exported object and as such can file a suit for restitution in normal proceedings of civil matters on personal property. ${ }^{14}$. An ultimate sort of procedure has been to sue for a declaratory judgement declaring that the object has been exported illegally and thereby proventing auction houses, dealers and museums to sell or to buy this object. ${ }^{15}$

b) The requesting State has to prove that its export legislation has been violated and that the removal of the object impairs its interests mentioned in Art. 5(3).

c) The return may only be refused if the object has a close connection with the culture of the State addressed (Art. 6) or if the claim for return has not been filed within five years after the requesting State knew or should have known the location of the illegally exported object or the identity of its possessor: Art. 7(b).

d) The Convention does not apply to cultural objects of modern times because it does not want to interfere with the international art trade in modern art. Such an inference would seriously infringe the rights of modern artists and their heirs. ${ }^{16}$

e) The return of illegally exported objects does not necessarily touch the ownership and the possession of these objects: Art. 8(2). A purchaser in good faith is entitled to fair and reasonable compensation if he does not want to retain ownership and possession: Art. $8(1)$ and $8(2)$.

\subsection{Claims and Actions}

Actions under this Convention may be filed in the courts of the State where the possessor of the cultural object has its habitual residence or of the State where the object is located: Art. 9(1).

\subsection{Entry into Force and Reservations}

a) The Convention will have no retroactive effect. It will apply only to those objects which have been stolen or illegally exported after entry into force of the Convention in the forum State: Art. 10.

b) The Convention is designed as a minimum convention. Therefore the Contracting States are free to extend the treaty provisions to objects or situations not covered by the Convention: Art. 11. 


\section{Proposals for Amendment}

The first session of the committee of government experts took place in Rome from May 6-10, 1991. ${ }^{17}$ The main questions discussed at this meeting and to be considered until the next session of the committee of government experts are mainly concerning three matters.

\subsection{Scope of Application}

There was a general consensus that the Convention should cover the return of stolen cultural objects and the restitution of illegally exported pieces of property of the same kind.

a) Some delegates wanted to extend the Convention. The definition of 'cultural object' in Art. 2 should also comprise objects of archaeological and scientific significance ${ }^{18}$ and items from clandestine excavations ought to be considered as stolen objects and subjected to Chapter II. ${ }^{19}$ Some delegations voted to delete Art. 5(3) concerning the interests of the requesting State ${ }^{20}$ and to lengthen the limitation periods of Arts. 3(2) and 7(b). ${ }^{21}$ This would also extend the application of the Convention. The same is true if the Convention would apply retroactively at least with regard to stolen cultural objects. ${ }^{22}$ b) There were also arguments to limit the scope of application: The notion of 'cultural objects' had to be defined more cautiously and be limited to objects of 'great' cultural significance; ${ }^{23}$ Chapter II on the return of stolen objects should be restricted to international situations and to thefts committed in a Contracting State; ${ }^{24}$ the limitation period of Arts. 3(2) and 7(b) ought to be shortened or at least formulated more flexible in order to take account of the parties' behaviour; ${ }^{25}$ and finally Art. 11 was considered to be abolished so that there would be no freedom to apply the more liberal domestic rules of the forum state. ${ }^{26}$

\subsection{Important Details}

In several respects the preliminary draft has been criticised and additional research and deliberations have been found necessary:

a) In Art. 3 the different persons who may sue for the return of a stolen object should be mentioned as well as the several potential defendants who may be 'possessors' and as such be obliged to return stolen objects. Also the term 'stolen' needs some clarification as this term may differ in various jurisdictions. ${ }^{27}$ In Art. 8(2) the remedies mentioned (compensation or retention of ownership) have to be clarified. ${ }^{28}$

b) There has been no consensus whether the 'fair and reasonable' compensation of a bona fide possessor, as provided in Arts. 4(2) and 8(1), should be kept, whether other persons different from the plaintiff may pay compensation and whether in Art. 8(1) the burden 
of proof for the possessor's good faith should really be borne by him. ${ }^{29}$

c) The possessor should be obliged to conserve and maintain the cultural object in its original condition (new Art. ' $X$ ') ${ }^{30}$ and therefore he ought to be compensated for his expenditures. ${ }^{31}$

\subsection{Compatability with Other Treaties}

The preliminary draft does not provide any rule about its relation to other treaties. Yet this problem has to be taken care of:

a) The UNESCO Convention of 1970 on Illicit Import, Export and Transfer of Cultural Property ${ }^{32}$ is the international instrument having the closest relations to the preliminary draft. Any conflict between these two treaties or any tension between them will be avoided if the preliminary draft tries to use the same notions (especially with respect to that of 'cultural object').

b) Reference has been made to Art. 36 of the EEC Treaty of Rome of 1956 which still exempts national treasures from the principle of free movement of goods within the Community. ${ }^{33}$ There are, however, already proposals for a regulation and a directive on matters of cultural property. ${ }^{34}$ The regulation will deal with the export of cultural property to countries outside of the Community. The directive will provide for the restitution of cultural objects which illegally have left a national territory of a Community State. As these proposals seem to favour a liberal movement of cultural property within the Community, there should be a general provision in the preliminary draft allowing to provide for a special regime within supranational communities.

c) Finally attention has been drawn to the Brussels Conventions of $1968 / 1978 / 1989$ on Jurisdiction and the Enforcement of Foreign Judgments in Civil and Commercial Matters and to the Lugano Convention of 1988 with the same title. ${ }^{35}$ As these Conventions provide that for specific matters special rules of jurisdiction and enforcement of foreign decisions may be introduced (Art. 57 of the Brussels Convention, Art. 57 of the Lugano Convention), the preliminary draft should also regulate the enforcement of judgments and some problems arising out of Art. 6 when the State in which the object is located has a closer connection to the object than the requesting State.

\section{Some Critical Observations}

\subsection{Notion of Cultural Objects}

The preliminary draft prefers a very broad notion of 'cultural object' to be interpreted uniformally without reference to any national law or national description. This has been criticised and limitations of 
various kinds have been put forward. ${ }^{36}$ I doubt very much whether such endeavours will be successful. Not all countries have registers of cultural objects being of outstanding or great importance for the State. Therefore the notion 'cultural object' cannot be limited to registered cultural objects. Likewise it would be unreasonable to mould this notion according to the discretion of the forum State. This would entail tremendous insecurity. I have the impression that the broad notion should be kept and that we should rely on the rules on compensation and on time limitations or claims for the return of stolen or illegally exported cultural property as indirect means to prevent capricious claims for restituion of such objects.

\subsection{Spatial Dimensions}

Some States have already challenged the ambition of the preliminary draft to prohibit bona fide purchases of cultural objects also in purely domestic cases. ${ }^{37}$ Although I agree with the preliminary draft, the national objections to it should be taken seriously. They need not stem from provincial prejudices or from national pride of domestic legislation. Also here the vague notion of the term 'cultural property' has a considerable impact on this hesitance to make exceptions to bona fide purchases and acquisitve prescriptions with respect to goods which cannot be defined exactly.

Therefore the draft should limit itself to international transactions and leave it to the discretion of the Contracting States whether they want to extend the rules for international transactions also to domestic ones. If such a restriction is made, there should, however, be an additional provision: Stolen objects cannot be recovered abroad if there has been a bona fide purchase in the State of theft. This implies at least two different conclusions. On the one hand an Italian painting stolen in Italy and sold in Italy to bona fide purchaser cannot be recovered by the original owner in Italy (because of Italian law) and therefore should not be restituted to him if sold abroad by the bona fide purchaser. On the other hand the additional provision would not bar any court to treat a foreign whitewashing of domestic cultural objects as illegal. In the English case Winkworth $v$ Christie's, ${ }^{38}$ e.g., the courts could therefore ignore that the English cultural objects, stolen in England, were acquired bona fide in Rome and then brought back to England to be sold at an auction.

\subsection{Plaintiffs and Defendants}

Art. 3(1) does not mention who is entitled to restitution. Hence every forum will have to decide under its rules of procedure and private international law whether the plaintiff has a claim against the possessor as defendant. In order to reduce this insecurity the draft should mention as plaintiffs the owner and everybody having a valid title for possession. The questions, however, as to ownership 
and possessory rights have to be answered according to rules of conflict of laws, including those of the UNIDROIT Convention, as soon as an international transaction has taken place.

In Art. 5 concerning the return of illegally exported cultural objects no specific defendant is mentioned. This could be justified because even the owner of the cultural object would have to return the object. ${ }^{39}$ Despite this it can easily be drafted that every person in possession of the cultural object, be it the owner or be it somebody else, is obliged to return the object.

\subsection{Time Limits}

The time limits within which an action has to be brought according to Arts. 3(2) and 7(b) are different for stolen, and for illegally exported cultural objects. As with all legislative decisions about time limits there may be arguments about their being too long or too short. I rather prefer a relative period of three years and an absolute one of twenty years. This, however, is not my point because I am aware that there may be good reasons for different attitudes. The main short-coming of every strict time limit is the strictness itself. It cannot pay regard to individual situations which are important. Negligence of the owner or of the requesting State to locate the cultural object can be taken into account because it can be argued that these plaintiffs could have reasonably known the location of the object or the identity of its possessor much earlier. But what about museums hiding stolen or illegally exported objects until the absolute time period has elapsed? To my impression the reservations of national law in Art. 11(a)(ii) and (b)(ii) are not a sufficient substitute for uniform regulations.

\subsection{Compensation}

According to Arts. 4(1) and 8(1) a bona fide possessor can sue for 'reasonable compensation'. If the defendant really is a bona fide possessor there is no justification for having' him to bear-the risk that the owner did not pay regard to his property or that the requesting State did not effectively enforce its export legislation. The bona fide possessor and all people who honestly preserved and restored the object should be fully compensated for their expenses (purchase price or costs of restoration). Whether there should be a common fund of the Contracting States to enable developing countries to pay this compensation or whether anybody else will do so, is another question which should be discussed at the next session of the Institute.

\subsection{Export Legislation}

The requesting State should be bound to furnish detailed information to the State addressed about its export legislation, the contents 
and practice of export administration and any particulars necessary to evaluate the claim for return of illegally exported property. Such a clarification should be included into Art. 5 which really is of extraordinary importance and which, to a large extent, touches new dimensions of international cooperation in private international law.

\section{Final Remarks}

The preliminary draft Convention of UNIDROIT has an inherent weakness typical for so many international instruments: The Convention tries to treat all States (especially those of Chapter III on the return of illegally exported objects) alike although it is common knowledge how different many States care for their cultural property and protect it from being illegally exported. The same can be said of private owners and the very different degrees of their endeavours to avoid loss by theft and robbery. Nonetheless the preliminary draft uses neutral language and does not even mention the plaintiff's missing or insufficient care for his own cultural property as one of the circumstances which have to be taken into account for the plaintiff's remedy itself, for the burden of proof or for the defendant's claim for compensation. More than that, the draft in one instance at least completely ignores reality and states in Art. 5(3)(a): The return of illegally exported property should be ordered if the removal impairs the following interests (mentioned as the first one): 'the physical preservation of the object'. It may be that a Convention cannot face reality and pay due regard to situations hardly flattering to some deprived States and owners. Yet there should be some effort made to evaluate sincerely the supranational priorities in the field of protection of cultural property. Of course, the Convention cannot be a substitute for the preservation and maintenance of cultural objects in their countries of origin. There should, however, prevail the principle of protection of the single object itself over nationalistic emotions. At least in Chapter III the State addressed should be allowed to decline the return of illegally exported objects so long as the requesting State cannot guarantee that the object will be well preserved and maintained after its return. This would be a dilatory clause of cultural public policy and would empower the forum State to declare that there is an obligation to return the cultural object, but 'not yet' 40 .

\section{Notes}

1 Siehr, Kurt, Preliminary Draft Unidroit Convention on Stolen or Illegally Exported Cultural Objects (approved by the UNIDROIT Study Group on the International Protection of Cultural Property at its Third Session on 26 January 1990) (1992) 1 International Journal of Cultural Property 252-255. 
2 UNIDROIT 1986, C.D. 65 - Dec. 18. See also UNIDROIT Bulletin, no. 71/ 72, p. 5.

3 Draft Convention providing a uniform law on the acquisition in good faith of corporeal moveables, UNIDROIT 1975, Study XLV Doc. $58=$ Revue de droit uniforme 1975 I p. 68-83. Cp. Jean-Georges Sauveplanne, Rapport explicatif du projet de Convention portant loi uniforme sur l'acquisition de bonne foi d'object mobiliers corporel, (1975) Revue de droit uniforme I p. 84-116.

4 Cp. UNIDROIT 1990, Study LXX - Doc. 19. p. 7, and Gerte Reichelt, La protection internationale des biens culturels, (1985) Revue de droit uniforme I p. $42-153$ (42).

5 Supra n. 3.

6 Conventions and Recommendations of UNESCO concerning the protection of the cultural heritage (Paris 1983) p. 57; and in: (1971) 10 Int.Leg.Mat. p. 289.

7 Cp. the bibliography cited by Reichelt (supra n. 4) p. 148 et seq.

8 Document UNIDROIT: C.E.G./Biens culturels, lère session, Misc. 4.

9 UNIDROIT 1990 (supra n. 4) p. 16 (n. 26).

10 UNIDROIT 1990 (supra n. 4) p. 17-19.

11 UNIDROIT 1990 (supra n. 4) p. 22 et seq. (n. 43) and p. 33 (n. 73).

12 Cp., e.g., Attorney General of New Zealand v Ortiz, [1984] A.C. 41 (H.L.); Jeaneret v Vichey, 693 F. 2d 259 (2d Cir. 1982).

13 Cp. United States v Hollinshead, 495 F.2d 1154 (9th Cir. 1974); United States v McClain, 593 F.2d 658 (th Cri. 1979), cert. denied 444 U.S. 918 (1979).

14 Cp. Tribunale di Torino 25.3.1982 (Repubblica dell'Ecuador c. Danusso), (1982) 18 Rivista di diritto internationale privato e processuale p.625; Oberlandesgericht Schleswig 10.2.1989, (1989) Neue Juristische Wochenschrift p. 3105.

15 Cp. Kingdom of Spain v Christie, Manson \& Woods Ltd., [1986] 1 W.L.R. 1120 (Ch.).

16 UNIDROIT 1990 (supra n. 4) p. 31 (n. 65).

$17 \mathrm{Cp}$. Committee of government experts on the international protection of cultural property. Report on the first session (Rome, 6 to 10 May 1991), UNIDROIT 1991, Study LXX - Doc. 23.

18 Committee (supra n. 17) p. 9 et seq. (n. 41).

19 Committee (supra n. 17) p. 46 (new art. 12); Working papers submitted during the first session of the committee (Rome, 6 to 10 May 1991): UNIDROIT 1991, Study LXX - Doc. 22, p. 22 (proposal of the delegation of Mexico).

20 Committee (supra n. 17) p. 29 (n. 106).

21 Committee (supra n. 17) p. 14 and 15 (nos. 57-59).

22 Committee (supra n. 17) p. 43 and 44.

23 Committee (supra n. 17) p. 8 (N. 35 ).

24 Committee (supra n. 17) p. 7 (nos. 33 and 34) and p. 12 (n. 49).

25 Committee (supra n. 17) p. 15 (n. 60) and p. 37 and 38 (n. 131).

26 Committee (supra n. 17) p. 44 and 45 (nos. 158-163).

27 Committee (supra n. 17) p. 13 (n. 54).

28 Committee (supra n. 17) p. 39 and 40 (nos. 139-144).

29 Committee (supra n. 17) p. 38 and 39 (n. 136).

30 Committee (supra n. 17) p. 46.

31 Committee (supra n. 17 ) p. 17 (n. 56).

32 Supra n. 6.

33 Committee (supra n. 17) p. 10 (n. 44), p. 32 and 33 (n. 116), p. 47 (n. 168). 
34 Loredana Fenoglio, Il David lasci pure l'Italia, basta che resti nella Cee ..., (July/August 1991) $8 \mathrm{Il}$ giornale dell'arte p. 1 and 3; Joanna Goyder, European Community - Free Movement of Cultural Goods and European Community Law, (1992) 1 International Journal of Cultural Property 219-225.

35 Committee (supra n. 17) p. 41 and 42 (nos. 147-150).

36 Supra at $\mathrm{n} .18$ and $\mathrm{n} .19$.

37 Supra at n. 24.

38 Winkworth v Christie, Manson \& Woods Ltd, [1980] 1 All ER 1121. 2 WLR 937 (Ch.D.).

39 Cp., e.g., Jeanneret v Vichy, 693 F.2d 259 (2d Cir. 1982).

40 Cp. For more details: Kurt Siehr, paper presented in May 1990 in Heidelberg, to be published in the papers of this conference. 